\title{
ANALISIS PENGARUH NON PERFORMING FINANCING (NPF), CAPITAL ADEQUACY RATIO (CAR), FINANCING TO DEPOSIT RATIO (FDR), DAN BOPO TERHADAP PROFITABILITAS (STUDI KASUS PADA PT. BANK VICTORIA SYARIAH PERIODE 2011-2016)
}

\author{
Wahyu Dwi Yulihapsari, Dien Noviany Rahmatika dan Jaka Waskito \\ PT. Bank Victoria Syariah, Univ. Pancasakti Tegal dan Universitas Pancasakti Tegal \\ wahyudwiyulihapsari@gmail.com
}

\begin{abstract}
This study was conducted to examine the effect of variable Non Performing Financing (NPF), Capital Adequacy Ratio (CAR), Financing to Deposit Ratio (FDR) and ROA to profitability PT. Bank Victoria Syariah as measured by Return on Assets (ROA). Data used in the study was obtained from the Quarterly Financial Report 2011-2016 period issued by PT. Bank Victoria Syariah. The total sample of 21 with the technique of multiple regression analysis and hypothesis testing using t-test and $F$ test with a significance level of 5\%, which preceded the classical assumption. The results showed the dependent variable profitability (ROA) of $94.7 \%$ can be explained by variations in four independent variables (NPF, CAR, FDR and ROA) .In partial NPF and ROA significant negative effect on ROA, CAR significant positive effect on ROA, and FDR was not significant positive effect on ROA. Simultaneously NPF, CAR, FDR and BOPO effect on ROA.
\end{abstract}

Keywords : Non Performing Financing (NPF), Capital Adequacy Ratio (CAR), Financing to Deposit Ratio (FDR), ROA and Return on Assets (ROA)

\section{PENDAHULUAN}

Eksistensi perbankan syariah di Indonesia saat ini semakin meningkat sejak adanya Undang-Undang No. 21 Tahun 2008 tentang Perbankan Syariah yang memberikan landasan operasi yang lebih jelas bagi bank syariah. Hal ini tampak dari perkembangan kelembagaan perbankan syariah di mana pada tahun 1992, hanya ada satu Bank Umum Syariah yang beroperasi di Indonesia yaitu Bank Muamalat Indonesia dan 9 BPRS.

Penting bagi bank untuk senantiasa menjaga kinerjanya dengan baik, terutama dalam menjaga dan memper- tahankan tingkat profitabilitas yang tinggi. Salah satu cara mengetahui keberhasilan perbankan ialah dengan melihat rasio kinerja keuangannya (Mudrajad dan Suhardjono, 2002:16). Laporan keuangan merupakan salah satu informasi keuangan yang bersumber dari intern perusahaan, menunjukkan kinerja keuangan masa lalu dan menunjukkan posisi keuangan saat ini (Sudarini, 2005:198).

Profitabilitas merupakan indikator yang paling tepat untuk mengukur kinerja suatu bank. Pada umumya ukuran profitabilitas yang digunakan adalah Return on Equity (ROE) dan Return on Asset (ROA). ROA mem- 
fokuskan kemampuan manajemen bank dalam menghasilkan income dari pengelolaan aset perusahaan yang dimiliki, sedangkan ROE menunjukkan kemampuan manajemen bank dalam mengelola modal yang tersedia untuk mendapatkan net income. Dalam menentukan tingkat kesehatan bank yang pada akhirnya dapat mencerminkan keberlanjutan kinerja keuangan suatu bank, Bank Indonesia lebih mementingkan penilaian besarnya laba berdasarkan ROA karena Bank Indonesia lebih mengutamakan nilai profitabilitas suatu bank yang diukur dengan assets yang sebagian besar dananya dihimpun dari simpanan masyarakat (Dendawijaya, 2005:74). Dalam Peraturan Bank Indonesia (PBI) No.9/1/PBI/2007 Tentang Sistem Penilaian Tingkat Kesehatan Bank Umum Berdasarkan Prinsip Syariah disebutkan bahwa penialaian tingkat kesehatan bank dapat dinilai melalui permodalan (Capital), kualitas aset (Asset Quality), manajemen (Management), rentabilitas (Earning), likuiditas (Liquidity) dan sensitivitas terhadap risiko pasar (Sensitivity to Market Risk). Aspek Capital meliputi Kewajiban Penyediaan Modal Minimum (KPMM) atau CAR, aspek Asset Quality meliputi NPF, aspek Earnings meliputi Return On Equity, Return On Asset,dan BOPO, dan aspek Liquidity meliputi FDR.

Penelitian terkait pengaruh CAR, BOPO, NPF, dan FDR terhadap ROA telah banyak dilakukan yang bisa dilihat pada bagian penelitian terdahulu. Namun, tidak terdapat konsistensi hasil dalam penelitian-penelitian tersebut (research gap). Mahardian (2008) dalam penelitian "Analisis Pengaruh CAR, BOPO, NPL, NIM, dan LDR terhadap ROA (Studi Kasus Pada Bank Umum di Indonesia Periode Juni 2002-Juni 2007)" menyebutkan bahwa CAR, NIM dan LDR berpengaruh positif dan signifikan terhadap ROA. Sedangkan BOPO berpengaruh signifikan negatif dan NPL berpengaruh negatif tidak signifikan terhadap ROA. Ahmad Buyung Nusantara (2009) dalam "Analisis pengaruh NPL, CAR, LDR, dan BOPO terhadap profitabilitas bank pada bank umum go public dan bank umum non go public di Indonesia periode tahun 2005-2007" mengatakan bahwa untuk kategori bank go publik NPL dan BOPO berpengaruh negatif signifikan, sedangkan CAR dan LDR berpengaruh positif signifikan terhadap ROA paada bank go publik di Indonesia periode 2005-2007. Untuk kategori bank non go publik NPL, CAR, dan BOPO berpengaruh positif tidak signifikan dan hanya LDR yang berpengaruh positif signifikan terhadap ROA. Fitri Zulfiah dan Joni Susilowibowo (2014) dalam "Analisis pengaruh Inflasi, Capital Adequacy Ratio (CAR), Non Performing Finance (NPF), Biaya Operasional dan Pendapatan Operasional (BOPO) terhadap Profitabiitas Bank Umum Syariah Periode 2008-2012" memperoleh kesimpulan CAR dan NPF berpengaruh positif terhadap ROA, BI rate dan BOPO berpengaruh negatif terhadap ROA, namun inflasi tidak berpengaruh terhadap ROA. Secara bersama-sama inflasi, BI rate, CAR, NPF dan BOPO berpengaruh signifikan terhadap ROA. Erika Amelia (2015) pada penelitian "Financial Ratio And Its Influences to Profitability In Islamic Banks" menyimpulkan CAR, NPF, FDR berpengaruh negatif tidak signifikan terhadap ROA, sedangkan BOPO berpengaruh negatif signifikan terhadap ROA. Dari beberapa penelitian terdahulu tersebut, terdapat research gap sehingga diperlukan adanya penelitian lebih lanjut. Tujuan dari penelitian ini adalah untuk menganalisis pengaruh NPF, CAR, FDR dan BOPO terhadap profitabilitas (ROA) baik secara parsial maupun simultan pada 
Bank Victoria Syariah periode 20112016.

\section{TELAAH PUSTAKA}

\section{Profitabilitas}

Profitabilitas menurut Malayu Hasibuan (2006:104) adalah kemampuan bank dalam menghasilkan laba. Sedangkan menurut Siamat (2005) bahwa rasio profitabilitas digunakan untuk mengukur efektifitas bank dalam memperoleh laba. Disamping dapat dijadikan sebagai ukuran kesehatan keuangan, rasio-rasio profitabilitas ini sangat penting untuk diamati mengingat keuntungan yang memadai diperlukan untuk mempertahankan arus sumber-sumber modal. Dendawijaya (2005:73) menjelaskan tingkat ROA digunakan untuk mengukur profitabilitas bank karena Bank Indonesia sebagai pembina dan pengawas perbankan lebih mengutamakan nilai profitabilitas suatu bank yang diukur dari aset yang dananya berasal dari sebagian besar dana simpanan masyarakat. Semakin besar ROA suatu bank, semakin besar pula tingkat keuntungan yang dicapai bank dan semakin baik posisi bank tersebut dari segi penggunaan asset. ROA adalah salah satu bentuk dari rasio profitabilitas untuk mengukur kemampuan perusahaan dalam menghasilkan laba dengan menggunakan total aktiva yang ada. Suatu bank dapat dimasukkan ke dalam klasifikasi sehat apabila rasio tingkat pengembalian atau ROA mencapai sekurang-kurangnya $1,2 \%$ (Malayu, 2006;45).

\section{Non Performing Financing (NPF)}

Termin NPL (Non Performing Loan) diperuntukkan bagi bank umum, sedangkan NPF (Non Performing Financing) untuk bank syariah., timbul karena masalah yang terjadi dalam proses persetujuan pembiayaan di internal bank, atau setelah pembiayaan diberikan. NPF mencerminkan risiko kredit, semakin tinggi NPF mengakibatkan semakin tinggi tunggakan bunga kredit yang berpotensi menurunkan pendapatan bunga serta menurunkan laba. Demikian sebaliknya, semakin rendah NPF akan semakin tinggi pendapatan bunga dan laba (Muljono, 1999:54). Dengan demikian, semakin besar jumlah saldo pembiayaan bermasalah yang dimiliki bank, akan semakin besar jumlah dana cadangan yang harus segera disediakan, serta semakin besar pula biaya yang harus mereka tanggung untuk mengadakan dana cadangan itu. Sudah barang tentu hal ini mempengaruhi profitabilitas usaha bank yang bersangkutan. Bank Indonesia menetapkan kriteria rasio NPF gross kurang dari 5\%.

\section{Capital Adequacy Ratio (CAR)}

CAR merupakan rasio permodalan yang menunjukkan kemampuan bank dalam menyediakan dana untuk keperluan pengembangan usaha dan menampung risiko kerugian dana yang diakibatkan oleh kegiatan operasi bank. CAR menunjukkan sejauh mana penurunan aset bank masih dapat ditutup oleh equity bank yang tersedia, semakin tinggi CAR semakin baik kondisi sebuah bank (Tarmidzi Achmad, 2003:63). Modal bank adalah total modal yang berasal dari bank yang terdiri dari modal inti dan modal pelengkap. Modal inti yaitu modal milik sendiri yang diperoleh dari modal disetor oleh pemegang saham. Modal inti terdiri dari modal disetor, agio saham, cadangan umum, cadangan tujuan, laba ditahan, laba tahun lalu, laba tahun berjalan, dan bagian kekayaan anak perusahaan yang laporan keuangannya dikonsolidasikan. Modal pelengkap terdiri dari cadangan revaluasi aktiva tetap, cadangan penghapusan aktiva yang diklasifikasikan, modal 
kuasa, dan pinjaman subordinasi. Sedangkan ATMR merupakan penjumlahan ATMR aktiva neraca dengan ATMR administratif. Muljono (1999:63) mengemukakan bahwa Bank Indonesia mengklasifikasikan bank dalam 3 kelompok : (1) Bank sehat dengan klasifikasi A, jika memiliki CAR lebih dari $8 \%$, (2) Bank take over (BTO) atau dalam penyehatan oleh BPPN (Badan Penyehatan Perbankan Nasional) dengan klasifikasi B, jika bank tersebut memiliki CAR antara $-25 \%$ sampai dengan $<$ dari 8\%, (3) Bank Beku Operasi (BBO) dengan klasifikasi C, jika memiliki CAR kurang dari $-25 \%$. Bank dengan klasifikasi $\mathrm{C}$ inilah yang dilikuidasi.

\section{Financing to Deposit Ratio (FDR)}

FDR atau sama halnya dengan Loan Deposit Ratio (LDR) pada bank konvensional merupakan rasio yang digunakan untuk mengukur likuiditas suatu bank dalam membayar kembali penarikan dana yang dilakukan deposan dengan mengandalkan pembiayaan yang diberikan sebagai sumber likuiditasnya, yaitu dengan cara membagi jumlah pembiayaan yang diberikan oleh bank terhadap Dana Pihak Ketiga (DPK). Semakin tinggi FDR maka semakin tinggi dana yang disalurkan ke Dana Pihak Ketiga (DPK). Dengan penyaluran Dana Pihak Ketiga (DPK) yang besar maka pendapatan bank ROA akan semakin meningkat, sehingga FDR berpengaruh positif terhadap ROA. Standar yang digunakan Bank Indonesia untuk rasio FDR adalah 80\% hingga $110 \%$. Jika angka rasio FDR suatu bank berada pada angka di bawah $80 \%$ dapat dikatakan bahwa bank tersebut tidak menjalankan fungsinya dengan baik. Kemudian jika rasio FDR bank mencapai lebih dari $110 \%$, berarti total pembiayaan yang diberikan bank tersebut melebihi dana yang dihimpun.

\section{Biaya Operasional Terhadap Penda- patan Operasional (BOPO)}

Rasio Biaya Operasi terhadap Pendapatan Operasional (BOPO) atau yang sering disebut rasio efisiensi digunakan untuk mengukur kemampuan manajemen bank dalam mengendalikan biaya operasi terhadap pendapatan operasional. Biaya operasi merupakan biaya yang dikeluarkan oleh bank dalam rangka menjalankan aktivitas usaha pokoknya (seperti biaya bagi hasil, biaya tenaga kerja, biaya pemasaran dan biaya operasi lainnya). Biaya operasional bank terdiri dari biaya bagi hasil, biaya jual beli valuta asing, biaya pegawai dan Penyusutan. Pendapatan operasional merupakan pendapatan utama bank yaitu pendapatan bunga/margin yang diperoleh dari penempatan dana dalam bentuk pembiayaan dan penempatan operasi lainnya (Almilia dan Herdingtyas, 2005:141). Pendapatan Bank terdiri dari pendapatan margin, Pendapatan operasional lainnya (penerimaan dividen yang berasal dari anak perusahaan) dan pendapatan non-operasional (pendapatan yang berasal dari penjualan aktiva), serta pendapatan atas transaksi valuta asing. Pendapatan transaksi valas timbul dari transaksi valuta asing yang berasal dari selisih kurs nilai mata uang antar-negara. Semakin kecil BOPO menunjukkan semakin efisien bank dalam menjalankan aktifitas usahanya atau dengan kata lain semakin tinggi rasio BOPO maka kemungkinan bank dalam kondisi bermasalah semakin besar. Dengan kata lain, BOPO berhubungan negatif dengan kinerja bank sehingga diprediksikan juga berpengaruh negatif terhadap perubahan laba.

\section{Pengaruh NPF terhadap ROA}

NPF merupakan rasio yang dipergunakan untuk mengukur kemampuan bank dalam mengcover risiko pengem- 
balian pembiayaan oleh debitur. Bank dalam memberikan pembiayaan harus melakukan analisis terhadap kemampuan debitur untuk membayar kembali kewajibannya. Setelah pembiayaan diberikan, bank wajib melakukan pemantauan terhadap penggunaan pembiayaan serta kemampuan dan kepatuhan debitur dalam memenuhi kewajibannya. Bank juga dapat melakukan peninjauan, penilaian dan pengikatan terhadap agunan untuk memperkecil risiko pembiayaan. NPF mencerminkan risiko pembiayaan, semakin tinggi NPF mengakibatkan semakin tinggi risiko pembiayaan bermasalah yang berpotensi akan menurunkan keuntungan yang diperoleh. Demikian sebaliknya, semakin rendah NPF, maka ROA akan semakin tinggi ataupun sebaliknya jika NPF tinggi maka akan membuat ROA semakin menurun. Menurut Mahardian (2008:94), yang melakukan penelitian "Analisis pengaruh CAR, BOPO, NPL, NIM dan LDR terhadap ROA (Studi kasus pada bank umum di Indonesia periode Juni 2002Juni2007) didapatkan kesimpulan bahwa NPL berpengaruh negatif tidak signifikan terhadap ROA.

\section{Pengaruh CAR terhadap ROA}

CAR merupakan indikator terhadap kemampuan bank untuk menutupi penurunan aktivanya sebagai akibat dari kerugian-kerugian bank yang disebabkan oleh aktiva yang berisiko dengan kecukupan modal yang dimilikinya. Tri Widyastuti dan Mandagie (2010:25) melakukan penelitian tentang pengaruh CAR, NIM, dan LDR terhadap ROA pada Perusahaan Perbankan yang terdaftar di Bursa Efek Indonesia (BEI) selama 2004-2008, dari penelitian ini diperoleh kesimpulan bahwa CAR memiliki pengaruh positif dan signifikan terhadap ROA.

\section{Pengaruh FDR terhadap ROA}

Almilia dan Herdiningtyas (2005:147), menyatakan FDR (Financing to Deposit Ratio)/LDR mengukur kemampuan bank dalam membayar kembali kewajiban kepada para nasabah yang telah menanamkan dana dengan pembiayaan yang telah diberikan kepada para debiturnya. FDR tersebut menyatakan seberapa jauh kemampuan bank dalam membayar kembali penarikan dana yang dilakukan deposan dengan mengandalkan pembiayaan yang diberikan sebagai sumber likuiditasnya. Semakin tinggi rasio tersebut memberikan indikasi semakin tinggi juga kemampuan likuiditas bank yang bersangkutan. Oleh karena itu semakin tinggi likuiditas bank tersebut maka kinerja perusahaan semakin meningkat.

\section{Pengaruh BOPO terhadap ROA}

BOPO merupakan rasio antara biaya operasional terhadap pendapatan operasional (Dendawijaya, 2005). BOPO digunakan untuk mengukur kemampuan manajemen bank dalam mengendalikan biaya operasional terhadap pendapatan operasional. Rasio BOPO menunjukkan rasio efisiensi perusahaan, karena semakin efisien biaya operasional yang dikeluarkan oleh bank). Semakin kecil angka rasio BOPO, maka kondisi bermasalah di bank semakin kecil. Jika kondisi bermasalah di bank semakin kecil maka kemungkinan kondisi bank semakin baik. Kondisi bank yang semakin baik akan menyebabkan kinerja perusahaan juga mengalami peningkatan. Fitri Zulfiah dan Joni Susilowibowo (2014:759-770) menganalisis analisis pengaruh Inflasi, Capital Adequacy Ratio (CAR), Non Performing Finance (NPF), Biaya Operasional dan Pendapatan Operasional (BOPO) terhadap Profitabiitas Bank Umum Syariah Periode 2008-2012 diperoleh hasil 
bahwa BOPO berpengaruh negatif terhadap ROA. Hal ini sejalan dengan penelitian yang dilakukan Mahardian (2008:94) yang menganalisis pengaruh CAR, BOPO, NPL, NIM, dan LDR terhadap ROA (Studi Kasus Pada Bank Umum di Indonesia Periode Juni 2002-Juni 2007) dimana penelitian mereka menunjukkan bahwa BOPO berpengaruh signifikan negatif terhadap ROA. Maka dalam penelitian ini penulis mengajukan hipotesis:

$\left(\mathrm{H}_{1}\right)$ Diduga ada pengaruh negatif signifikan NPF terhadap ROA

$\left(\mathrm{H}_{2}\right)$ Diduga ada pengaruh positif signifikan CAR terhadap ROA

$\left(\mathrm{H}_{3}\right)$ Diduga ada pengaruh positif signifikan FDR terhadap ROA

$\left(\mathrm{H}_{4}\right)$ Diduga ada pengaruh negatif signifikan BOPO terhadap ROA

$\left(\mathrm{H}_{5}\right)$ Diduga secara simultan ada pengaruh yang signifikan NPF, CAR, BOPO dan FDR terhadap ROA

\section{METODE PENELITIAN}

Variabel independen (X) dalam penelitian ini adalah NPF, CAR, FDR dan BOPO, sedangkan variabel dependen (Y) adalah ROA. NPF merupakan rasio antara pembiayaan bermasalah terhadap pembiayaan yang disalurkan. Menurut Bank Indonesia rasio ini dirumuskan sebagai berikut:

$\mathrm{NPF}=\frac{\text { Pembiayaan Bermasalah }}{\text { Total Pembiayaan }} \times \quad 100 \%$

CAR adalah rasio yang memperlihatkan seberapa besar jumlah seluruh aktiva bank yang mengandung resiko (pembiayaan, penyertaan, surat berharga, tagihan pada bank lain) ikut dibiayai dari modal sendiri disamping memperoleh dana-dana dari sumber-sumber diluar bank. Bank Indonesia merumuskan rasio ini sebagai berikut:

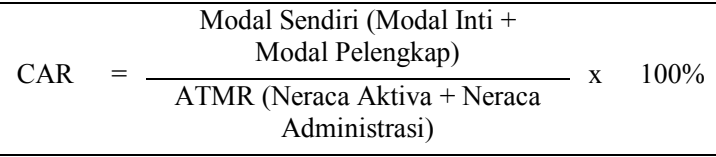

FDR merupakan rasio antara pembiayaan yang diberikan terhadap total dana pihak ketiga. FDR ini dimaksudkan untuk mengukur kemampuan bank dalam memenuhi pembayaran kembali deposito yang telah jatuh tempo kepada deposannya serta dapat memenuhi permohonan pembiayaan yang diajukan tanpa terjadi penangguhan. Rasio ini dirumuskan sebagai berikut:

FDR $=\frac{\text { Jumlah Dana yang Diberikan }}{\text { Total Dana Pihak Ketiga }} \times \quad 100 \%$

Biaya Operasional terhadap Pendapatan Operasional (BOPO) sering disebut rasio efisiensi ini digunakan untuk mengukur kemampuan manajemen bank dalam mengendalikan biaya operasional terhadap pendapatan operasional. Semakin kecil rasio ini berarti semakin efisien biaya operasional yang dikeluarkan bank yang bersangkutan sehingga kemungkinan suatu bank dalam kondisi bermasalah semakin kecil. Rasio ini dirumuskan sebagai berikut:

BOPO $=\frac{\text { Total Beban Operasional }}{\begin{array}{c}\text { Total Pendapatan } \\ \text { Operasional }\end{array}} \times \quad 100 \%$

Jenis data yang digunakan dalam penelitian ini adalah data sekunder sehingga langkah yang dilakukan adalah dengan mencatat seluruh data yang diperlukan dalam penelitian ini sebagai mana yang tercantum di Laporan Triwulan Bank Victoria Syariah periode tahun 2011-2016. Populasi yang digunakan dalam penelitian ini adalah perusahaan PT. Bank Victoria Syariah sampel sebanyak 21 sampel. Metode analisis yang digunakan dalam penelitian ini adalah metode kuantitatif dan alat analisis yang digunakan adalah analisis 
regresi berganda dengan melakukan uji asumsi klasik terlebih dahulu. Adapun uji asumsi klasik yang terdiri dari uji normalitas, uji multikolinearitas, dan uji heteroskedatisitas. Hasil uji normalitas dengan bantuan menggunakan bantuan program SPSS 16.

Hasil pengujian masing-masing variabel menunjukkan bahwa tidak terjadi atau bebas gejala normalitas, multikolinieritas, heteroskedastisitas, dan autokorelasi. Teknik yang digunakan untuk mengetahui pengaruh variabel independen terhadap variabel dependen, dengan menggunakan rumus regresi linear berganda sebagai berikut: $Y=a+$ $b 1 X 1+b 2 X 2+b 3 X 3+b 4 X 4+e$. Selanjutnya, teknik uji hipotesis menggunakan uji $\mathrm{R}^{2}$, uji $\mathrm{F}$ dan uji t. Uji $\mathrm{R}^{2}$ digunakan untuk mengukur seberapa jauh kemampuan model dalam menerangkan variasi variabel dependen. Uji F digunakan untuk mengetahui pengaruh secara bersama-sama variabel independen terhadap variabel dependen. Uji t dalam penelitian ini digunakan untuk mengetahui pengaruh secara parsial variabel independen terhadap variabel dependen, maka dengan uji inilah akan diketahui variabel bebas mana yang lebih dominan berpengaruh pada variabel dependen (Ghozali, 2012).

\section{HASIL PENELITIAN DAN PEM- BAHASAN HASIL PENELITIAN}

Setelah memenuhi uji asumsi klasik yang meliputi uji normalitas, uji multikolinearitas, uji heterokedastisitas, dan uji autokorelasi, kemudian dilakukan analisis regresi linier berganda dengan hasil yang terdapat pada tabel 1 sebagai berikut :
Tabel 1 : Hasil Perhitungan Regresi Linier Berganda

\begin{tabular}{|c|c|c|c|c|c|}
\hline \multirow[b]{2}{*}{ Model } & \multicolumn{2}{|c|}{$\begin{array}{l}\text { Unstandardized } \\
\text { Coefficients }\end{array}$} & \multirow{2}{*}{$\begin{array}{c}\begin{array}{c}\text { Standardized } \\
\text { Coefficients }\end{array} \\
\text { Beta }\end{array}$} & \multirow[b]{2}{*}{$\mathrm{t}$} & \multirow[b]{2}{*}{ Sig. } \\
\hline & B & $\begin{array}{l}\text { Std. } \\
\text { Error }\end{array}$ & & & \\
\hline (Constant) & 2,836 & 1,865 & & 1,520 & , 148 \\
\hline NPF &,- 284 & ,367 &,- 121 &,- 775 & 449 \\
\hline CAR & 197 & ,027 & ,720 & 7,386 & ,000 \\
\hline FDR & ,008 & ,020 & 061 & ,386 & ,705 \\
\hline ВОРО &,- 060 & ,014 & -304 & $4,270^{-}$ & ,001 \\
\hline
\end{tabular}

Dengan melihat Tabel 1 di atas, dapat disusun persamaan regresi linear berganda :

Profitabilitas $=2,836-0,284 \mathrm{X}_{1}+$ $0,197 \mathrm{X}_{2}+0,008 \mathrm{X}_{3}-0,60 \mathrm{X}_{4}$

Dari hasil perhitungan $\mathrm{Uji}^{2}$ diperoleh nilai koefisien determinasi (Adjusted $\mathrm{R}^{2}$ ) sebesar 0,947 atau 94,7\% hal ini berarti $94,7 \%$ variasi ROA yang bisa dijelaskan oleh variasi dari empat variabel bebas yaitu NPF, CAR, FDR, dan BOPO sedangkan sisanya sebesar $5,3 \%$ dijelaskan oleh sebab-sebab lain diluar model. Nilai Standar eror of estimasi (SEE) yakni sebesar 0, 75097, dan semakin kecil nilai SEE akan membuat regresi semakin tepat dalam memprediksi variabel dependen. hasil perhitungan diperoleh nilai $\mathrm{F}$ hitung sebesar 91,219 yang lebih besar dari $\mathrm{F}$ tabel sebesar 3,01 dan nilai signifikansi sebesar 0,000. Karena nilai signifikansi lebih kecil dari 5\% maka variabel independen secara bersama-sama berpengaruh terhadap variabel dependen dan model layak.

Perhitungan secara parsial dengan menggunakan uji $\mathrm{T}$ diperoleh nilai $t_{\text {hitung }}$ sebesar $(-0,775)$ dengan nilai signifikansi sebesar 0,449 . Karena nilai signifikansi lebih besar dari 5\% dan nilai $t_{\text {hitung }}(-0,775)$ lebih kecil dari $t_{\text {tabel }}$ $(1,746)$ sehingga mengindikasikan adanya pengaruh tidak signifikan antara variabel NPF terhadap variabel ROA. Untuk variabel CAR, nilai $t_{\text {hitung }}$ sebesar 
7,386 yang lebih besar dari $t_{\text {tabel }}$ sebesar 1,746 dengan nilai signifikansi sebesar 0,000. Karena nilai signifikansi lebih kecil dari $5 \%$ dan nilai $t_{\text {hitung }}(7,386)$ lebih besar dari $t_{\text {tabel }}(1,746)$ berarti ada pengaruh signifikan antara CAR dengan ROA. nilai $t$ hitung pada variabel FDR sebesar $(0,386)$ dengan nilai signifikansi sebesar 0,705 . Karena nilai signifikansi lebih besar dari $5 \%$ dan nilai $t$ hitung $(0,386)$ lebih kecil dari $t$ tabel $(1,746)$ maka FDR berpengaruh tidak signifikan terhadap ROA. Pada variabel BOPO nilai $t$ hitung sebesar $(-4,270)$ dengan nilai signifikansi sebesar 0,001 . Karena nilai signifikansi lebih kecil dari 5\% dan nilai $\mathrm{t}$ hitung $(-4,270)$ lebih besar dari $\mathrm{t}$ tabel $(1,746)$ maka ada pengaruh signifikan antara BOPO dengan ROA.

\section{PEMBAHASAN}

\section{Pengaruh NPF terhadap ROA}

Berdasarkan hasil regresi menunjukkan adanya pengaruh tidak signifikan antara variabel NPF terhadap variabel ROA. Hasil temuan ini sejalan dengan hasil penelitian yang dilakukan oleh Mahardian (2003) dimana NPL tidak berpengaruh signifikan terhadap ROA. Tanda negatif pada hasil pengujian menunjukkan bahwa NPF memiliki pengaruh yang negatif pada ROA. Artinya semakin tinggi NPF mengakibatkan semakin tinggi tunggakan pembiayaan yang berpotensi menurunkan laba. Rasio NPF diperoleh rata-rata sebesar 3,4305\% hal ini menunjukkan bahwa secara statistik selama periode penelitian, rasio NPF masih dibawah standar yang ditetapkan Bank Indonesia yaitu tidak lebih dari 5\%. Penyaluran pembiayaan ke pihak debitur yang masih kecil yang disebabkan oleh kekhawatiran dari pihak bank jika pembiayaan yang diberikan menjadi bermasalah diduga menjadi penyebab mengapa pada penelitian ini NPF tidak berpengaruh signifikan terhadap ROA. Hal ini dibuktikan dengan tingkat rata-rata FDR yang masih tergolong rendah yaitu $76,3419 \%$. Standar yang ditetapkan oleh Bank Indonesia untuk FDR yaitu 80$110 \%$. Kondisi yang belum normal ini menyebabkan fungsi intermediasi yang diemban oleh bank menjadi tidak optimal. Sehingga walaupun rata-rata NPF yang tercatat berada dibawah 5\%, tidak menyebabkan naiknya ROA.

\section{Pengaruh CAR terhadap ROA}

Berdasarkan hasil regresi menunjukkan adanya pengaruh signifikan antara variabel CAR dengan variabel ROA. Hasil penelitian ini mendukung penelitian yang dilakukan oleh Buyung Nusantara (2009) yang menunjukkan hasil adanya pengaruh positif dan signifikan antara CAR terhadap ROA. Hasil penelitian ini mengindikasikan bahwa semakin tinggi CAR yang dicapai oleh bank menunjukkan kinerja bank semakin baik, sehingga pendapatan bank semakin meningkat. Perhitungan rasio CAR diperoleh rata-rata sebesar $25,5962 \%$. Hal ini menunjukkan bahwa secara statistik, selama periode penelitian rasio CAR sudah memenuhi standar yang ditetapkan Bank Indonesia. Bank Indonesia mengklasifikasikan bank dalam kelompok sehat dengan klasifikasi A jika memiliki CAR lebih dari $8 \%$,

\section{Pengaruh FDR terhadap ROA}

Dari hasil perhitungan uji regresi, hasil uji menunjukkan FDR berpengaruh tidak signifikan terhadap ROA. Nilai positif yang ditunjukkan FDR menunjukkan bahwa semakin tinggi FDR menunjukkan semakin tinggi ROA. Akan tetapi, rasio rata-rata FDR yang hanya $76,3419 \%$ masih dibawah standar yang ditetapkan oleh Bank Indonesia yaitu 80-110\%., sehingga FDR masih tergolong rendah. Kemampuan bank dalam menyalurkan dana dari pihak 
ketiga kepada pihak peminjam masih belum optimal sehingga ini menyebabkan FDR tidak signifikan dalam mempengaruhi ROA.

\section{Pengaruh BOPO terhadap ROA}

Dari perhitungan uji secara parsial diperoleh hasil ada pengaruh signifikan antara BOPO dengan ROA. Hasil penelitian ini sesuai dengan penelitian Mahardian (2008) yang menyatakan bahwa BOPO berpengaruh negatif dan signifikan terhadap ROA. Hal ini berarti tingkat efisiensi bank dalam menjalankan operasinya,berpengaruh terhadap tingkat pendapatan atau "earning" yang dihasilkan oleh bank tersebut. Jika kegiatan operasional dilakukan dengan efisien (dalam hal ini nilai rasio BOPO rendah) maka pendapatan yang dihasilkan bank tersebut akan naik. Pada penelitian ini rasio rata-rata BOPO sebesar 98,4910\% sedangkan standar yang ditetapkan Bank Indonesia kurang dari 93,5\%. hal tersebut menunjukkan bahwa manajemen masih kurang efisien dalam menjalankan aktivitas operasionalnya.

\section{Pengaruh NPF, CAR, FDR BOPO secara simultan terhadap ROA}

Dari perhitungan uji secara simultan diperoleh hasil variabel independen NPF, CAR, FDR dan BOPO secara simultan (bersama-sama) berpengaruh terhadap variabel dependen profitabilitas (ROA). Hasil penelitian ini sesuai dengan penelitian Fitri Zulfiah dan Joni Susilowibowo (2014) yang menyatakan bahwa secara simultan inflasi, BI rate, CAR, NPF dan BOPO berpengaruh signifikan terhadap ROA pada Bank Umum Syariah di Indonesia tahun 2008-2012. Artinya jika terjadi perubahan terhadap NPF, CAR, FDR dan BOPO akan berpengaruh terhadap ROA.

\section{KESIMPULAN}

Berdasarkan Uji Determinasi diperoleh hasil $94,7 \%$ variasi profitabilitas (ROA) dapat dijelaskan oleh variasi keempat variabel independen (NPF,CAR, FDR dan BOPO), sedangkan sisanya 5,3\% dijelaskan oleh variabel lain yang tidak diteliti. Berdasarkan hasil pengujian statistik uji t, variabel NPF berpengaruh negatif tidak signifikan terhadap ROA, CAR berpengaruh signifikan positif terhadap ROA, FDR berpengaruh positif tidak signifikan terhadap ROA dan BOPO berpengaruh negatif signifikan terhadap variabel ROA. Berdasarkan hasil analisis data dengan uji $\mathrm{F}$, dapat disimpulkan pada variabel independen NPF, CAR, FDR dan BOPO secara simultan (bersama-sama) berpengaruh terhadap variabel dependen profitabilitas (ROA).

\section{IMPLIKASI KEBIJAKAN}

Hasil Penelitian ini menunjukkan bahwa rasio-rasio keuangan bank pada PT. Bank Victoria Syariah hanya CAR dan BOPO yang mampu memprediksi ROA dengan signifikan. Sisi positif dari hasil penelitian ini adalah mempertegas hasil penelitian sebelumnya (Mahardian, 2008) yang meneliti bagaimana pengaruh Capital Adequacy Ratio (CAR), Efisiensi Operasi (BOPO), Non Performing Loan (NPL), Net Interest Margin (NIM), dan Loan to Deposit Ratio (LDR) terhadap Return on Asset (ROA) sebagai proksi dari kinerja keuangan perbankan yang tercatat di BEJ. Bagi PT. Bank Victoria Syariah diharapkan agar pihak manajemen bank mampu mengoperasikan modal yang tersedia melalui kegiatan operasional perbankan, sehingga CAR yang tinggi mampu meningkatkan profitabilitas perbankan dan tidak menjadi dana yang menganggur serta menekan biaya operasional dan meningkatkan pendapatan 
operasional dengan cara menekan biaya promosi, meminimalkan pembiayaan bermasalah, dan efisiensi terhadap kinerja karyawan, sehingga profit yang dihasilkan akan maksimal. PT. Bank Victoria Syariah hendaknya juga meningkatkan nilai Financing to Deposit Ratio (FDR) yaitu dengan mengoptimalkan penyaluran pembiayaan dari dana pihak ketiga kepada masyarakat sehingga profitabilitas juga dapat lebih optimal. Pergerakan rasio BOPO haruslah menjadi perhatian khusus agar perusahaan selalu berada pada tingkat efisiensi yang bisa menghasilkan laba yang maksimal, sehingga kinerja yang dicapai akan selalu meningkat.

Bagi investor, rasio ini perlu diperhatikan sebagai salah satu bahan pertimbangannya dalam menentukan strategi investasinya. Sementara dari pihak regulator (Bank Indonesia) diharapkan selalu memperhatikan perkembangan rasio BOPO bank-bank yang berada dalam pengawasannya agar kinerja keuangan yang dicapai bankbank tersebut dapat selalu meningkat.

\section{DAFTAR PUSTAKA}

Achmad, tarmizi dan willyanto kartiko kusuno. 2003. "Analisis rasio-rasio keuangan sebagai predictor dalam memprediksi potensi kebangkrutan perbankan di Indonesia", Media Ekonomi dan Bisnis. vol.XV,No.1,Juni 2003: 54-75.

Ali, Masyud. 2004. Asset Liability Management: Menyiasati Risiko Pasar dan Risiko Operasional, Jakarta:PT Gramedia.

Al-Jafari, Mohamed Khaled, and Mohammad Alchami. 2014. "Determinants of Bank Profitability: Evidence from Syria”. Journal of Applied Finance \& Banking. Volume 4, No. 1, 2014.

Almilia \& herdaningtyas. 2005. "Analisis rasio Camel terhadap prediksi kondisi bermasalah pada lembaga perbankan 2000-2002",Jurnal Akuntansi dan keuangan, vol 7, no.2. November 2005: 131-147.

Amelia, Erika. 2015. "Financial Ratio And Its Influence To Profitability In Islamic Banks”, Al-Iqtishad, Vol. VII No. 2, Juli 2015: 229-240.

Andreani Caroline B \& David Sulistyo, 2011. "Hubungan efisiensi operasional dengan kinerja profitabilitas pada sektor perbankan yang go public di Bursa Efek Jakarta”. Jurnal Wira Ekonomi Mikroskil, Vol 1, no.02. Oktober 2011: 89-97.

Bank Indonesia, 1999. Surat Keputusan Direksi Bank Indonesia No. 32/34/Kep/DIR tanggal 12 Mei 1999 tentang "Bank Umum Berdasarkan Prinsip Syariah", Jakarta : Bank Indonesia.

2001. Surat Edaran Bank Indonesia No 3/30 DPNP tanggal 14 Desember 2001 perihal "Laporan Keuangan Publikasi Triwulanan dan Bulanan Bank Umum serta Laporan tertentu yang disampaikan kepada Bank Indonesia”, Jakarta : Bank Indonesia.

2004. Surat Edaran Bank Indonesia No.6/73/Intern DPNP tanggal 24 Desember 2004 perihal "Pedoman Sistem Penilaian Tingkat Kesehatan Bank Umum (CAMELS Rating)”, Jakarta : Bank Indonesia. 
2005

Laporan

Pengawasan

Perbankan.

http://bi.go.id/id/publikasi/perbankan-dan-stabilitas/laporan

pengawasan/Pages/lpp2.aspx

2007. Peraturan Bank Indonesia No.9/1/PBI perihal "Sistem Penilaian Tingkat Kesehatan Bank Umum Berdasarkan Prinsip Syariah”, Jakarta : Bank Indonesia.

, 2007. Surat Edaran Bank Indonesia No. 9/24/DPbS tanggal 30 Oktober 2007 perihal "Sistem Penilaian Tingkat Kesehatan Bank Umum Berdasarkan Prinsip Syariah”, Jakarta : Bank Indonesia. , 2016. http://bankvictoriasyariah.co.id/page/sub/triwulan.

Buchory, Herry Achmad. 2014. "Analysis Of The Effect Of Capital, Credit Risk, Profitability to implementation banking intermediation function (Study On Regional Development Bank All Over Indonesia Year 2012)", International Journal of Business, Economics and Law, Vol. 4, ISSN 2289-1552.1 Juni 2014.

Dendawijaya, Lukman.2005, Manajemen Perbankan, Jakarta: Penerbit Ghalia.

Fitri Zulifiah \& Joni Susilowibowo, 2014. "Pengaruh Inflasi, Capital Adequacy Ratio (CAR), Non Performing Finance (NPF), Biaya Operasional dan Pendapatan Operasional (BOPO) terhadap Profitabilitas Bank Umum Syariah Periode 2008-2012”, Jurnal Ilmu Manajemen Volume 2 Nomor 3, Juli 2014.

Gujarati, Damodar. 1999. Ekonometrika Dasar, Jakarta: Penerbit Erlangga.

Hasibuan, Malayu. 2006. Dasar-Dasar Perbankan. Jakarta : Penerbit Bumi Aksara.

Ikatan Akuntan Indonesia, 2007. Standar Akuntansi Keuangan, Pernyataan Standar Akuntansi Keuangan no.31 Tentang Akuntansi Perbankan. Jakarta : Penerbit Salemba Empat.

2007. Standar Akuntansi Keuangan, Pernyataan Standar Akuntansi Keuangan no.59 Tentang Akuntansi Perbankan Syariah. Jakarta : Penerbit Salemba Empat.

2010. Standar Akuntansi Keuangan. Jakarta : Penerbit Salemba Empat.

Imam Ghozali, 2006. Aplikasi Analisis Multivariate dengan program SPSS, Semarang : Badan Penerbit UNDIP.

Karim, Adiwarman Azwar. 2006. Bank Islam : Analysis Fiqih dan Keuangan, Edisi Ketiga. Jakarta : Rajawali Pers.

Kasmir. 2005. Manajemen Perbankan. Jakarta : PT Raja Grafindo Persada.

Kuncoro, Mudrajad, dan Suhardjono. 2002. Manajemen Perbankan Teori dan Aplikasinya. Yogyakarta : BPFE.

Kumar, Suresh. 2014, "Non Performing Assets: An Indian Perspective". International Journal of Academic Research in Economics and Management Sciences. Volume 3, No. 2, Maret 2014. 
Mabruroh, 2004, "Manfaat Pengaruh Rasio Keuangan dalam Analisis Kinerja Keuangan Perbankan," Benefit, Vol.8, No.1, Juni 2004.

Mahardian, Pandu. 2008. " Analisis Pengaruh CAR, BOPO, NPL, NIM, dan LDR terhadap ROA (Studi Kasus Pada Bank Umum di Indonesia Periode Juni 2002-Juni 2007).” Tesis Program Pasca Sarjana Magister Manajemen (tidak dipublikasikan). Semarang : Universitas Diponegoro.

Mamduh, M. Hanafi. 2005. Analisis Laporan Keuangan, Edisi Kedua. Yogyakarta: UPP AMP YKPN.

Muhammad, 2005. Pengantar Akuntansi Syariah, Edisi 2. Jakarta : Salemba Empat.

Muljono, Teguh Pudjo. 1999. Aplikasi Akuntansi Manajemen Dalam Praktek Perbankan. Edisi 3. Yogyakarta : BPFE.

Munawir. 2007. Analisis Laporan Keuangan. Yogyakarta: BPFE.

Nasution, Chaeruddin Syah Nasution, 2003. "Manajemen Kredit Syariah Bank Muamalat", Jurnal kajian Ekonomi dan Keuangan, Volume 7 Nomor 3, September 2003 : 84-99.

Nusantara, Buyung A. 2009. "Analisis Pengaruh NPL, CAR, LDR, dan BOPO Terhadap Profitabilitas Bank". Tesis. Program Pasca Sarjana Magister Manajemen (tidak dipublikasikan). Semarang : Universitas Diponegoro.

Okky Paulin \& Sudarso Kaderi Wiryono, 2015. "Determinants Of Islamic Bank's Profitability In Indonesia For 2009-2013", Journal Of Business and Management, Volume 4 Nomor 1, 2015 : 175-185.

Purbaningsih, Rr. Yoppy Palupi. 2014. "The Effect of Liquidity Risk and Non Performing Financing (NPF) Ratio to Commercial Sharia Bank Profitability in Indonesia” STIE EKUITAS, DOI: 10.7763/IPEDR. 2014. V73. 12, 2014.

Purnama, Gagah Edward. 2009. “Analisis Pengaruh Capital Adequacy Ratio (CAR), Loan To Deposit Ratio(LDR),Size, BOPO terhadap profitabilitas (Studi Perbandingan Pada Bank Domestik dan Bank Asing Periode Januari 2003Desember 2007)". Tesis. Program Pasca Sarjana Magister Manajemen (tidak dipublikasikan). Semarang : Universitas Diponegoro.

Riyadi, Slamet. 2006. Banking Assets And Liability Management. Edisi Ketiga. Jakarta: Fakultas Ekonomi Universitas Indonesia.

Riyanto, Bambang. 2001. Dasar-Dasar Pembelanjaan Perusahaan. Yogyakarta : BPFE.

Republik Indonesia. 1998. Undang-Undang Republik Indonesia Nomor 10 tahun 1998 tentang Perbankan. Sekretariat Negara. Jakarta.

2008. Undang-Undang Republik Indonesia Nomor 21 tahun 2008 tentang Perbankan Syariah. Sekretariat Negara. Jakarta

Robinson, Thomas R, Paul Munter \& Julia Grant, 2004. Financial Statement Analysis : A Global Perspective. New Jersey : Pearson Education International.

Siamat, Dahlan. 2005. Manajemen Lembaga Keuangan edisi keempat, Jakarta : Badan Penerbit Fakultas Ekonomi Universitas Indonesia. 
Sinungan, Muchdarsyah. 2000. Manajemen Dana Bank, Edisi kedua, Jakarta : PT. Bumi Aksara.

Sudarini, Sinta. 2005. "Penggunaan Rasio Keuangan Dalam Memprediksi Laba pada Masa Yang Akan Datang," Jurnal Akuntansi dan Manajemen, Vol. XVI No.3, Desember 2005: 195-207.

Sofyan, Sofriza. 2003. "Pengaruh Struktur Pasar Terhadap Kinerja Perbankan di Indonesia." Media Riset Bisnis dan Manajemen, Vol. 2 No. 3, Desember 2003: 194-219.

Tri Widyastuti \& Yuana Rizky Octaviani Mandagie, 2010. "Pengaruh CAR, NIM, dan LDR terhadap ROA pada Perusahaan Perbankan yang terdaftar di Bursa Efek Indonesia (BEI) selama 2004-2008”. Akuntabilitas Vol 10 No.1 ,September 2010:18-25.

Wiyono, Slamet. 2005. Cara Mudah Memahami Akuntansi Perbankan Syariah Berdasarkan PSAK \& PAPSI. Jakarta : PT. Gramedia Widiasarana Indonesia. 